\title{
Biodiversity of Talitridae family (Crustacea, Amphipoda) in some Tunisian coastal lagoons
}

\author{
Raja Jelassi ${ }^{1 *}$, Hajer Khemaissia ${ }^{1}$, Martin Zimmer $^{2}$, Dieter Garbe-Schönberg ${ }^{3}$ and Karima Nasri-Ammar ${ }^{1}$
}

\begin{abstract}
Background: Although wetlands were remarkable habitats with their fauna and flora diversity, few studies have been devoted to the study of amphipod distribution in this type of environment.

To study both qualitatively and quantitatively amphipod community, surveys were conducted during the spring season in ten coastal lagoons ranging from subhumid to arid bioclimatic stage. At each station, eight quadrats of $50 \times 50 \mathrm{~cm}$ were randomly placed. Amphipods were preserved in alcohol $70^{\circ} \mathrm{C}$. In the laboratory, the specimens collected were identified and counted. Meanwhile, analyses of organic matter, particle size, and heavy metals from the soil taken from each station were made.

Results: A total of 1,340 specimens of amphipods were collected, and eight species belonging to Talitridae family were identified.

Species richness ranges from one species collected in the supralittoral zone of El Bcherliya (Ghar El Melh lagoon) and eight species in the supralittoral zone of Bizerte lagoon. In this last station, the relative abundance of amphipods was significantly higher $(36.04 \%, N=483)$. In addition, the diversity indices of Simpson, Shannon-Weaver, and equitability shows that the highest species diversity characterizes this same station while the community was more balanced in opposite El Boughaz (Ghar El Melh lagoon) $\left(J^{\prime \prime}=0.996\right)$.

Conclusions: The spatial distribution of different amphipod species depends on edaphic (heavy metals, granulometry, organic matter) and climatic (temperature, humidity) factors.
\end{abstract}

Keywords: Tunisia; Biodiversity; Lagoon; Amphipoda; Talitridae; Heavy metals

\section{Background}

Coastal areas, the natural interface between water and land, were valuable ecosystems since they host high biodiversity levels (Defeo and McLachlan 2005; McLachlan and Brown 2006). Many human activities, such as fishing, land reclamation, engineering, shipping, and recreational activities, affect coastal ecosystems (McLachlan and Brown 2006; Schlacher et al. 2007). The impact of pollution in coastal areas was generally strong and the contaminants of main concern include persistent organic pollutants, oil, radionuclides, fertilizers, trace metals, and pathogens (Islam and Tanaka 2004). Trace metals were toxic and nondegradable elements that have adverse effects on living organisms (e.g., immunodeficiency, negative effect on metabolic processes and cell membrane permeability) (Ikem and Egiebor

\footnotetext{
* Correspondence: djelassi.raja@gmail.com

'Université de Tunis El Manar II, Faculté des Sciences de Tunis, Unité de recherche Bio-Écologie et Systématique Évolutive, Tunis, Tunisie Full list of author information is available at the end of the article
}

2005). Many of these elements occur naturally, but their input has been enhanced through the millennia by various human activities (mining, metallurgical and tanning industries, chemical plants, paper mills) (Islam and Tanaka 2004).

In the Mediterranean, there was a high diversity of wetlands (lagoon, lake, sebkhas, oued, hill reservoir and dam) that were of great importance in conservation biology, and they were considered among the most biologically diverse and productive ecosystems (Medail and Quezel 1999). They offer a wide variety of natural habitats for plants and aquatic animals as well as semiterrestrial and terrestrial. The interactions of biological (plants, animals, microorganisms, etc.) and physicochemical components (granulometry, temperature, humidity, etc.) of wetlands enable them to perform many ecological functions such as shoreline stabilization and water purification.

In Tunisia, semi-closed shallow lagoons were among the most sensitive areas to environmental stresses

\section{实}


(Benrejeb-Jenhani and Romdhane 2002). In general, lagoon sediments were considered reservoirs of many chemical pollutants, especially heavy metals, which represent the most prominent marine pollution agents (Phillips and Rainbow 1994) affecting local communities and human health (Förstner and Wittmann 1981; Boucheseiche et al. 2002). Hence, quality management of marine coastal environments becomes a priority for many countries.

Peracarid crustaceans have received special attention, because many of them were important components of soft sediment faunas (Dauvin et al. 1994) and were considered good indicators of water and sediment quality (Corbera and Cardell 1995; Alfonso et al. 1998). Further, detritivorous peracarids play an important role in the degradation of organic matter, in both aquatic and terrestrial habitats. Talitrid amphipods were key species in the energy flow of sandy shore ecosystems (Griffiths et al. 1983). Feeding on terrestrial and marine material, these species integrate the different sources of contamination and constitute an important source of food for many species of invertebrates, fishes, and birds (Griffiths et al. 1983; Wildish 1988; Bergerard 1989; Koch 1989). This group constitutes one of the dominant macrofaunal groups in sandy beaches (Dahl 1946; McLachlan and Jaramillo 1995). Their ecological relevance has justified worldwide studies, for instance with respect to their behavioral plasticity (Scapini and Fasinella 1990; Scapini et al. 1993; Scapini et al. 1995), locomotor activity rhythms (Nasri-Ammar and Morgan 2005, 2006; Ayari and NasriAmmar 2012a, b; Jelassi and Nasri-Ammar 2013; Jelassi et al. 2013a, b), the factors influencing their spatial distribution and oriented movements in sandy beach (Scapini and Quochi 1992; Borgioli et al. 1999; Scapini et al. 1999; Ayari and Nasri-Ammar 2011; Jelassi et al. 2012; Jelassi et al. 2013c), their behavioral strategies (Fallaci et al. 1999), and genetic structure of different populations (De Matthaeis et al. 1995; Bulnheim and Schwenzer 1999). With regard to biodiversity, along the European coasts, talitrid populations have been compared genetically to assess inter- and intraspecific variations (De Matthaeis et al. 1995). In terms of applied research, a number of articles have been published on trace metal $(\mathrm{Cu}, \mathrm{Zn}, \mathrm{Fe}, \mathrm{Cd}, \mathrm{Pb}$, $\mathrm{Mn}$, and $\mathrm{Ni}$ ) concentrations and bioaccumulation by talitrids and on their role in biomonitoring (Fialkowski et al. 2000; Rainbow et al. 1989; Weeks 1992). Studying the amphipod diversity in three different complexes, lagoons in Northern Tunisia, Jelassi et al. (2013c) showed that the abundance of different amphipod species at the three lagoon complexes in northern Tunisia could be best explained by the soil contents of several heavy metals.

In Tunisia, amphipod communities inhabiting the supralittoral zone of wetlands, other than sandy beaches (Jelassi and Nasri-Ammar 2013; Jelassi et al. 2012; Jelassi et al. 2013a), have not received much attention. Thus, aims of this study were to produce a list of amphipod species collected in the supralittoral zones of different lagoons, to estimate species richness, abundance, and density, and we focus on environmental factors that may control their spatial distribution.

\section{Methods \\ Study stations}

In total, ten stations belonging to the supralittoral zone of eight coastal lagoons distributed along the Tunisian coasts were studied (Figure 1). The lagoon is a stretch of salt water partially or completely separated from the open ocean by barriers of sand. These stations were S1: Bizerte lagoon (S1: 37¹3'8 $\left.{ }^{\prime \prime} 009^{\circ} 55^{\prime} 1^{\prime \prime} \mathrm{E}\right)$, three stations belonging to Ghar E Melh lagoon (S2: El Bcherliya $\left(37^{\circ} 10^{\prime} 03^{\prime \prime} \mathrm{N} 010^{\circ} 09^{\prime} 57^{\prime \prime} \mathrm{E}\right), \mathrm{S} 3$ : the old harbor $\left(37^{\circ} 10^{\prime}\right.$

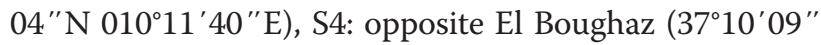
N 010 13'12"E), S5: Sidi Ali Mekki lagoon (3709'50"N 010 14'45"E)), S6: North (36 $\left.48^{\prime} 01^{\prime \prime} \mathrm{N} \quad 010^{\circ} 12^{\prime} 27^{\prime \prime} \mathrm{E}\right)$ and S7: South ( $\left.36^{\circ} 47^{\prime} 59^{\prime \prime} \mathrm{N} 010^{\circ} 12^{\prime} 26^{\prime \prime} \mathrm{E}\right)$ lagoons of Tunis, S8: Korba lagoon $\left(36^{\circ} 38^{\prime} 12^{\prime \prime} \mathrm{N} 010^{\circ} 54^{\prime} 11^{\prime \prime} \mathrm{E}\right)$, S9: Tazarka lagoon (36 $\left.32^{\prime} 20^{\prime \prime} \mathrm{N} 010^{\circ} 50^{\prime} 38^{\prime \prime} \mathrm{E}\right)$, and S10: El Bibane lagoon $\left(33^{\circ} 15^{\prime} 57^{\prime \prime} \mathrm{N} 011^{\circ} 08^{\prime} 28^{\prime \prime} \mathrm{E}\right)$.

\section{Sampling method and soil analysis}

Quantitative samples of amphipods were manually collected in spring (April 2010) during ten consecutive days in the early morning hours. In the supralittoral zone of each site, eight quadrats of $50 \times 50 \mathrm{~cm}$ were randomly placed and 20 min were devoted to collect amphipods inside the quadrat. The content of each quadrat $(7 \mathrm{~cm}$ depth) was placed in individual boxes. Humidity and temperature of soil were measured in situ at each site. In the laboratory, specimens were preserved in $70 \%$ ethanol. Afterwards, they were identified and counted. The identification of these species was carried out under a Leica MS 5 binocular microscope (Leica Microsystems, Wetzlar, Germany), using the key of Ruffo (1993) and Ruffo et al. (2014) (for the new name of Orchestia cavimana).

At each station, a soil sample was taken from a depth of 0 to $10 \mathrm{~cm}$. Grain size distribution of these composite samples was analyzed using different sieves in descending order (from $2 \mathrm{~mm}$ to $25 \mu \mathrm{m}$ ). A subsample was brought to the ICP-MS laboratory at University of Kiel and sieved to obtain the $<250-\mu \mathrm{m}$ grain size fraction which was then dried and milled (Bat and Raffaelli 1999). Heavy metals were extracted from a 250-mg sample of powder with $10 \mathrm{~mL} 7 \mathrm{~N}$ nitric acid on a hot plate at $80^{\circ} \mathrm{C}(2.5 \mathrm{~h})$. The solution was made up to $20 \mathrm{~mL}$, centrifuged at 3,500 rpm for $15 \mathrm{~min}$, and the supernatant transferred to a $20-\mathrm{mL}$ sample vial. The metals vanadium $(\mathrm{V})$, chromium $(\mathrm{Cr})$, manganese $(\mathrm{Mn})$, cobalt $(\mathrm{Co})$, nickel $(\mathrm{Ni})$, copper $(\mathrm{Cu})$, zinc $(\mathrm{Zn})$, arsenic $(\mathrm{As})$, cadmium $(\mathrm{Cd})$, tin $(\mathrm{Sn})$, thallium $(\mathrm{Tl})$, lead $(\mathrm{Pb})$, lithium 


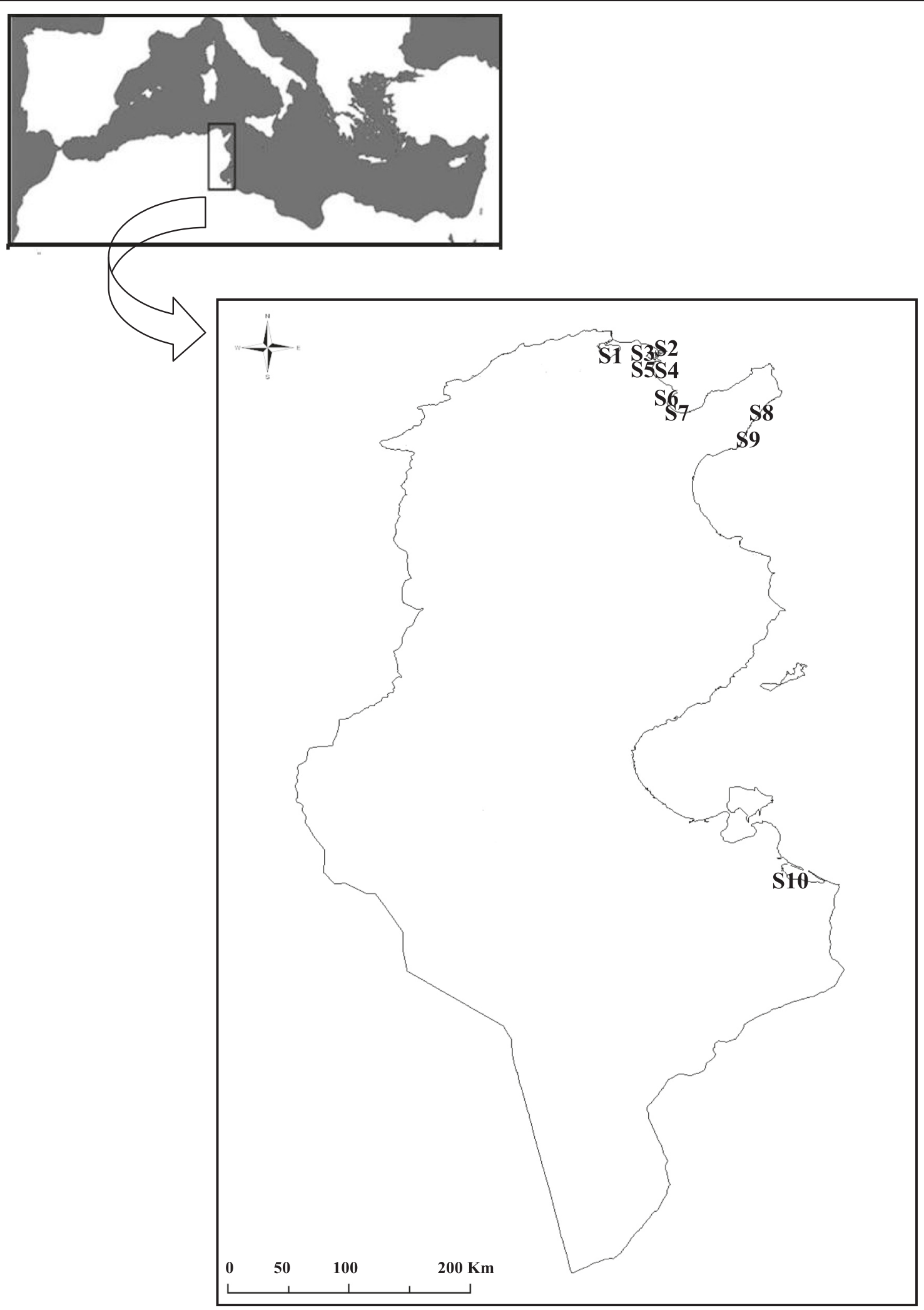

Figure 1 Localization of sampling lagoon stations. S1: Bizerte, S2: El Bcherliya, S3: Old harbor of Ghar El Melh, S4: Opposite El Boughaz, S5: Sidi Ali Mekki, S6: North lagoon of Tunis, S7: South lagoon of Tunis, S8: Korba, S9: Tazarka, S10: El Bibane. 
(Li), rubidium $(\mathrm{Rb})$, and strontium $(\mathrm{Sr})$ were analyzed by inductively coupled plasma-mass spectrometry (ICP-MS). Average analytical reproducibility was estimated from replicate analyses of some samples and was found to be better than 2\% RSD (1 sigma relative standard deviation) for all elements. The accuracy of analytical results was monitored by analyzing certified reference materials (CRM): GSMS-2 (marine sediment; Chinese Academy of Geological Sciences, PR China) and PACS-1 (coastal sediment; NRCC Canada) as unknowns along with the samples. Organic matter content was determined by weighing before and after ashing at $450^{\circ} \mathrm{C}$ for $3 \mathrm{~h}$ at the University of Salzburg.

Soil sodium content was determined by atomic absorption technique based on the methodology of the IC2MP (Institute of Chemistry of Poitiers: materials and natural resources). To obtain a usable sample, we put $5 \mathrm{~g}$ of soil in $50 \mathrm{ml}$ of distilled water. After $1 \mathrm{~h}$, the solution was filtered through a 50-lm mesh. To obtain reliable measurements, it was necessary to carry out successive dilutions.

\section{Data analysis}

In order to characterize the amphipod communities, the following ecological parameters were calculated: species richness $(S)$ expressed by the number of species at each station, occurrence frequency $(F=(n / N) * 100)$ where ' $n$ ' was the number of times that species appears in the sample and ' $N$ ' was the total number of samples, and relative species abundance $\left(A_{\mathrm{r}}=\left(n_{\mathrm{i}} / N\right) * 100\right)$ where ' $n_{\mathrm{i}}$ ' was the number of individuals of each species and ' $N$ ' was the total number of amphipods at each station. Mean density of the amphipod community at each station and the mean density of each species at each station were expressed as number of individuals per $\mathrm{m}^{2}$.

Species diversity and evenness were calculated by the Simpson index $\left(\mathrm{Is}=1 / \sum p_{\mathrm{i}}^{2}\right)$ with $p_{\mathrm{i}}=\left(n_{\mathrm{i}} / N\right) \quad(N=$ total number of amphipods; $n_{\mathrm{i}}=$ the number of individuals for each species) (Simpson 1949), the Shannon-Weaver index $\left(H^{\prime}=-\Sigma p_{\mathrm{i}} \log _{2} p_{\mathrm{i}}\right)$ (Frontier 1983), and Pielou's evenness index $\left(J^{\prime}=H^{\prime} / \log _{2} S\right)$ (Pielou 1966).

The degree of similarity among sampling stations was evaluated using similarity cluster dendrograms. For this analysis, the data matrix consisting of total abundances of species at each site was converted into a symmetric matrix using the Bray-Curtis similarity index. The similarity matrix was agglomerately clustered using complete linkage based on presence/absence of species. The analysis above was performed with the PRIMER software package (Clarke and Warwick 1994).

Differences in abundance, species richness, and densities of amphipod species among lagoons were tested using ANOVA test. Principal correspondence analysis (PCA) of amphipod distribution was performed using the free version of XLSTAT.

\section{Results}

Heavy metals, sodium, organic matter, and granulometry of different stations

The highest concentration of the majority of heavy metals, namely vanadium, nickel, zinc, arsenic, cadmium, thallium, and lead, was observed in the supralittoral zone of Tunis North lagoon. For the chromium and manganese, the maximum of content characterizes the supralittoral zone of Bizerte lagoon with respectively $26.393 \mathrm{ppm}$ and $281.748 \mathrm{ppm}$. The maximum content in copper (39.098 ppm) was observed in the supralittoral zone of El Bcherliya. The supralittoral zone of Korba lagoon revealed the highest concentration in cobalt $(8.311 \mathrm{ppm})$ and rubidium (15.814 ppm). Whereas, the supralittoral zone of El Bibane lagoon was characterized by the highest content in lithium $(29.087 \mathrm{ppm})$, in strontium $(2,101.549 \mathrm{ppm})$, and in tin $(7.340 \mathrm{ppm})$. Furthermore, the lowest concentration for all heavy metals studied was observed in the supralittoral zone of Sidi Ali Mekki.

The different heavy metals analyzed do not exceed the maximum value tolerated except for the lead that exceeded $100 \mathrm{ppm}$ in the supralittoral zone of Tunis North lagoon (Henin 1983).

In these different stations, soil sodium content ranged between $1.26 \mathrm{mg} / \mathrm{g}$ and $7.2 \mathrm{mg} / \mathrm{g}$ of soil in the supralittoral zone of Bizerte lagoon and the old harbor of Ghar El Melh, respectively. For the organic matter, the percentage varied between $0.6 \%$ in the supralittoral zone of Sidi Ali Mekki and $9.46 \%$ in the supralittoral zone of Bizerte lagoon.

Concerning the granulometry, the supralittoral zones of Bizerte lagoon, El Bcherliya, old harbor, Tunis North, and Korba were characterized by loamy sand substrates. The supralittoral zones of Tunis South and El Bibane lagoons were characterized by sandy substrates. The sandy loam, sandy clay loam, and sandy silt loam substrates characterized respectively the supralittoral zones of opposite El Boughaz, Tazarka, and Sidi Ali Mekki lagoons.

\section{Species richness and occurrence frequency}

A total of eight species were collected in lagoons namely Orchestia montagui Audouin, 1826, Orchestia mediterranea Costa, 1853, Orchestia gammarellus (Pallas, 1766), Orchestia stephenseni Cecchini, 1928, Cryptorchestia cavimana Heller, 1865, Platorchestia platensis (Kroyer, 1845), Deshayesorchestia deshayesii (Audouin, 1826) and Talitrus saltator (Montagu, 1808). Species richness varied both between quadrats of the same station and between lagoons. It ranged from one species in the supralittoral zone of El Bcherliya and eight species in the supralittoral zone of Bizerte lagoon (Table 1). The differences observed between lagoons were highly significant $(F=3.495, \mathrm{DF}=7, p=0.004)$. 
Table 1 Species composition, mean density and diversity indices of amphipod community in different lagoons

\begin{tabular}{|c|c|c|c|c|c|c|c|c|c|c|}
\hline & S1 & S2 & S3 & S4 & S5 & S6 & S7 & S8 & S9 & $\mathrm{S} 10$ \\
\hline Orchestia montagui & 41.5 & 0 & 0 & 0 & 0 & 15 & 30 & 0 & 0 & 28 \\
\hline Orchestia mediterranea & 62 & 0 & 18 & 9 & 3.5 & 17 & 33.5 & 0 & 0 & 25 \\
\hline Orchestia gammarellus & 45.5 & 0.5 & 19 & 10 & 3.5 & 34 & 34.5 & 0 & 0 & 25.5 \\
\hline Orchestia stephenseni & 32 & 0 & 5 & 12 & 0 & 16 & 32.5 & 0 & 0 & 5.5 \\
\hline Cryptorchestia cavimana & 17 & 0 & 0 & 0 & 0 & 0 & 0 & 0 & 0 & 0 \\
\hline Platorchestia platensis & 19 & 0 & 4 & 10 & 0 & 15 & 22 & 0 & 0 & 0 \\
\hline Deshayesorchestia deshayesii & 158 & 0 & 0 & 0 & 0.5 & 0 & 0 & 0 & 0 & 5.5 \\
\hline Talitrus saltator & 9.5 & 0 & 0 & 0 & 0 & 0 & 0 & 0 & 0 & 9.5 \\
\hline Total number of amphipod (N) & 483 & 1 & 92 & 82 & 15 & 194 & 275 & 0 & 0 & 198 \\
\hline S & 8 & 1 & 4 & 4 & 3 & 5 & 5 & 0 & 0 & 6 \\
\hline Is & 6.059 & 1 & 2.915 & 3.955 & 2.273 & 4.374 & 4.723 & - & - & 4.435 \\
\hline $\mathrm{H}^{\prime}$ & 2.771 & - & 1.711 & 1.992 & 1.287 & 2.232 & 2.278 & - & - & 2.309 \\
\hline$J^{\prime}$ & 0.924 & - & 0.855 & 0.996 & 0.812 & 0.961 & 0.981 & - & - & 0.893 \\
\hline
\end{tabular}

The study of the occurrence frequency of different species of amphipods on lagoon shores showed that $O$. gammarellus was qualified as common species $(F=80 \%)$ and, O. mediterranea $(F=70 \%)$ and O. stephenseni $(F=60 \%)$ were classified as constant species. As for P. platensis $(F=50 \%)$, O. montagui $(F=40 \%)$, and $D$. deshayesii $(F=30 \%)$, they were called accessory species. Finally, $T$. saltator $(F=20 \%)$ and $C$. cavimana $(F=10 \%)$ were qualified as rare species.

\section{Relative abundance and density}

A count of 1,340 amphipod individuals was collected in different lagoons. In this type of wetlands, the supralittoral zone of Bizerte lagoon revealed the highest abundance (36.04\%) (Table 1). Moreover, the difference between lagoons was statistically significant (Anova test: $F=4.371 ; \mathrm{DF}=7 ; p=0.001$.
The study of relative abundance of the different species showed that $O$. mediterranea was the most abundant species in the supralittoral zone of Bizerte lagoon (25.7\%). Whereas, in El Bcherliya, the old harbor of Ghar El Melh, the North and South lagoons of Tunis, O. gammarellus dominated the community. In the supralittoral zone of El Bibane lagoon, O. montagui was the most important species (28.3\%). Anova test revealed that differences in species observed between lagoons were highly significant $(F=4.371 ; \mathrm{DF}=7 ; p=$ $0.001)$.

Concerning the mean density of amphipod community, it varied between lagoons but it was the supralittoral zone of Bizerte lagoon that presented the important density with 241.5 ind. $\mathrm{m}^{-2}$. The lowest density was observed in the supralittoral zone of El Bcherliya (0.5 ind. $\mathrm{m}^{-2}$ ) (Figure 2).

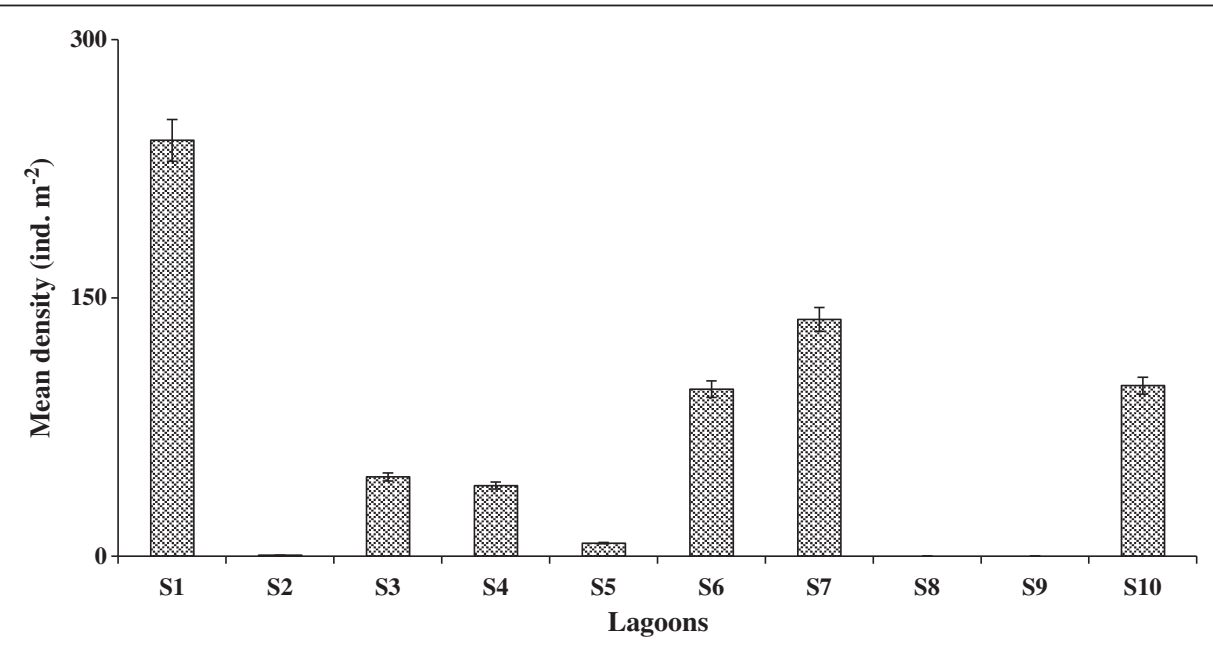

Figure 2 Variation of the mean density (ind. $\mathrm{m}-2$ ) of amphipod communities in the supralittoral zone of lagoons. 
Furthermore, results showed that O. mediterranea presented the most important density in the supralittoral zone of Bizerte lagoon (62 ind. $\mathrm{m}^{-2}$ ). Whereas, O. gammarellus showed the most important density in the supralittoral zones of El Bcherliya $\left(0.5\right.$ ind. $\left.\mathrm{m}^{-2}\right)$, the old harbor of Ghar El Melh (19 ind. $\mathrm{m}^{-2}$ ), the North (34 ind. $\mathrm{m}^{-2}$ ) and South (34.5 ind. $\mathrm{m}^{-2}$ ) lagoons of Tunis.

\section{Diversity and community similarity}

According to Simpson index, the highest diversity was observed in the supralittoral zone of Bizerte lagoon (Is =6.059) (Table 1). Unlike to the previous index, the Shannon-Weaver index takes into account much more the rare species, it confirmed this result and it ranged between 1.287 in the supralittoral zone of Sidi Ali Mekki lagoon and 2.771 in Bizerte lagoon. Concerning the equitability, it was important in opposite El Boughaz where we noted that the species were equitably distributed.

A dendrogram of similarity between lagoons, obtained by calculating the Bray-Curtis similarity index based on presence/absence of species, showed the presence of two clusters: the first associate Sidi Ali Mekki and El Bcherliya where we noted the lowest count of amphipods, the second associate the six others stations and it was divided into two sub-groups; the first combines the opposite El Boughaz and the old harbor of Ghar El Melh, and the other comprises North and South lagoons of Tunis, Bizerte lagoon, and El Bibane lagoon. The combination of these four stations could be explained on the one hand by the presence of the species $O$. montagui and on the other hand by a considerable concentration of lead exceeding $50 \mathrm{ppm}$ (Figure 3).

\section{Amphipod distribution according to environmental factors} Principal component analysis (PCA) was performed to better understand which of the environmental factors influenced the distribution of different species in lagoons (Figure 4).
The first three factorial axes (F1, F2, and F3) extract $54.39 \%, 19.57 \%$, and $9.32 \%$ of the variance respectively; it was a cumulative percentage of $83.28 \%$ (Figure 4 ).

On the first axis (F1) extracting almost half of the total inertia, there were Bizerte lagoon, North and south lagoons of Tunis which were correlated positively with the majority of heavy metals namely vanadium, chromium, manganese, cobalt, nickel, copper, zinc, arsenic, rubidium, cadmium, thallium, and lead. These stations were characterized negatively by the soil temperature.

On the second axis which extracts only $19.57 \%$ of the total variance, there were El Bcherliya, El Bibane and Korba lagoons which were related to soil humidity, particle size, and the content of strontium, lithium, and tin.

On the third axis, were projected negatively the organic matter and positively the concentration on sodium. These two parameters do not characterize these different lagoon stations.

\section{Discussion}

The study of biodiversity of amphipods communities highlighted differences in species richness, relative abundance and diversity between and within lagoons.

Globally the species richness was higher in the supralittoral zone of Bizerte lagoon than in the other stations. In this station, eight amphipod species were identified. This would be related to the presence of important vegetation in spring as well as the Cymodocea nodosa leaf litter and a high percentage of organic matter. In this same station, the highest diversity, abundance, and density were observed. Moreover, it was O. mediterranea that presented the most important density in this supralittoral zone. In other type of wetlands such as oueds, species richness varied between one species in oueds Laakarit, Khniss, and El Fared and six species in Tinja (Korsi station) whereas in sebkhas, only two species were collected in sebkhas Gargour and Moknine (Jelassi 2014; Jelassi

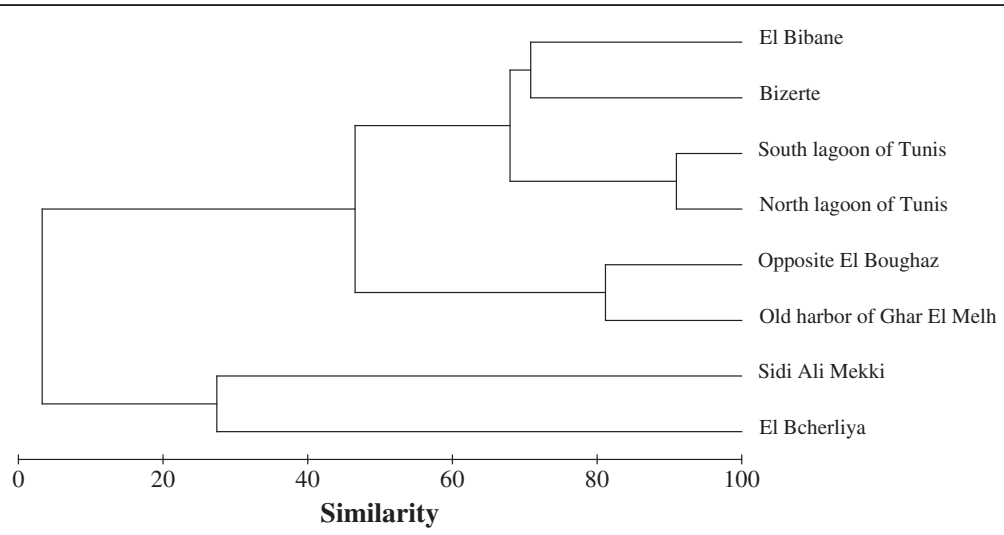

Figure 3 Clustering of sampling data, based on total number of amphipods collected (Bray-Curtis index, presence/absence, complete linkage). 


\section{Biplot (Axes F1 et F2 : 73.96\%)}
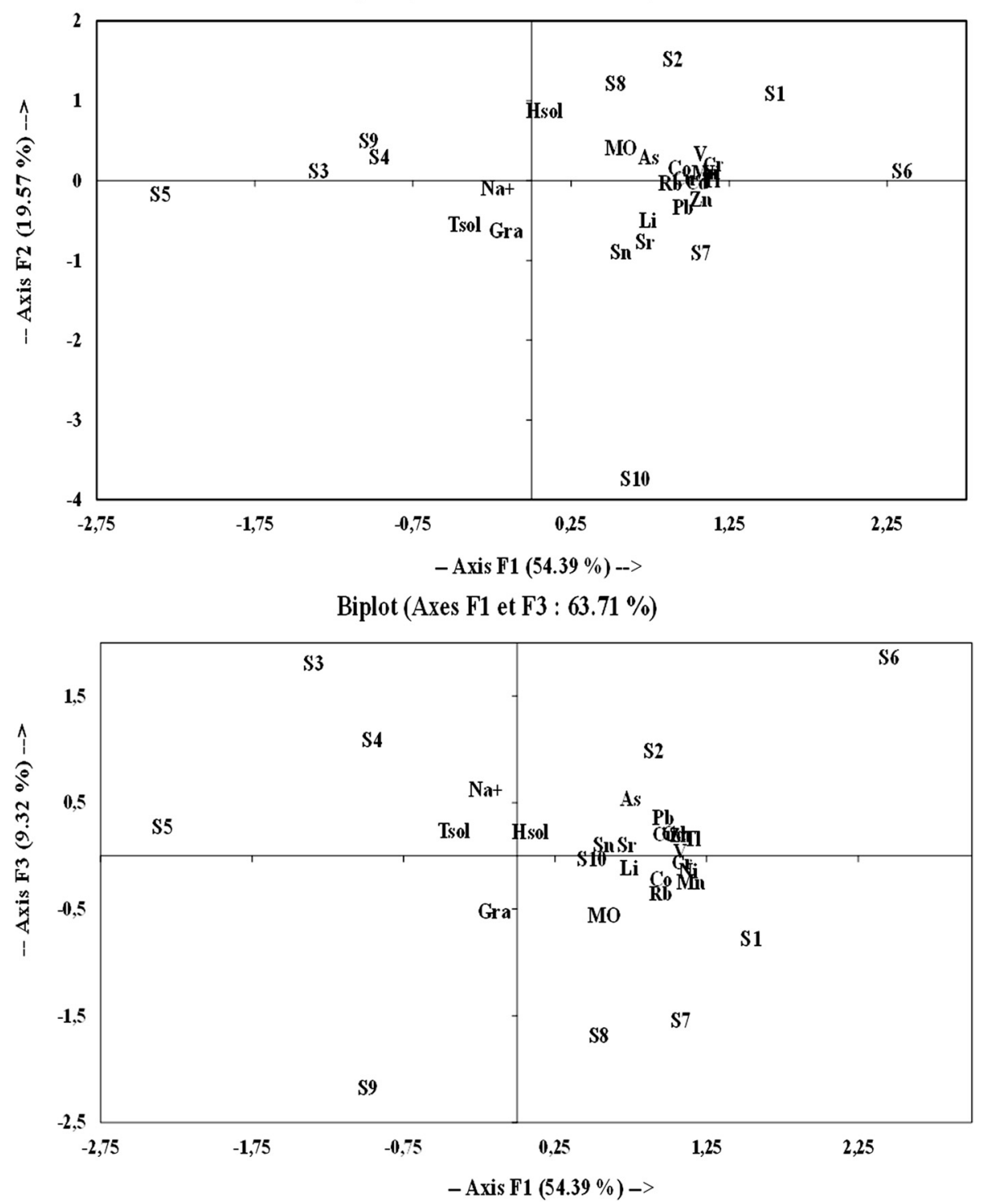

Figure 4 Principal Component Analysis (PCA) performed on the environmental factors. V: Vanadium, Cr: Chromium, Mn: Manganese, Co: Cobalt, Ni: Nickel, Cu: Copper, Zn: Zinc, As: Arsenic, Cd: Cadmium, Sn: Tin, Tl: Thallium, Pb: Lead, Li: Lithium, Rb: Rubidium, Sr: Strontium, Tsol: soil temperature, Hsol: soil humidity, Gra: granulometry, $\mathrm{Na}+$ : sodium, MO: organic matter.

et al. 2013c). In supralittoral zones of dams and hill lakes, no species has been found (Jelassi 2014). Using the same method of collection, Ayari (2012) showed the presence of five species namely $T$. saltator, $D$. deshayesii, O. gammarellus, O. montagui, and O. mediterranea in the supralittoral zone of Bizerte Corniche beach and only one species, $T$. saltator, in the supralittoral zone of Gabès beach. This author attributed the lowest species richness in the last station (Gabès) to the highest tidal amplitude reported in this beach and the highest species richness observed in Bizerte Corniche to the presence of Posidonia oceanica benches associated with other algae that provide shelter and food for different amphipod species. In Zouaraa beach, only two species were identified: T. saltator and Talorchestia brito living in sympatry with a total density generally low and never exceeded 860 ind. $\mathrm{m}^{-2}$ (Charfi-Cheikhrouha et al. 2000). At Ouderef, Gabes, and Zarrat beaches (Gulf of Gabes, Tunisia), the amphipod T. saltator was the most abundant species, present in the three beaches studied; with the highest densities in Ouderef beach (PérezDomingo et al. 2008). O. montagui and D. deshayesii in the Bay of Bou Ismail reached more than 45.000 ind. $\mathrm{m}^{-2}$ (Louis 1980), and O. mediterranea in the estuary of Bou Regreg, Morocco, attained 7,000 ind. $\mathrm{m}^{-2}$ (Elkaïm et al. 
1985). On the Isle of Man, densities of T. saltator were estimated at 80 to 400 ind. $\mathrm{m}^{-2}$ (Williams, 1995). Marsden (1991) and Cardoso and Veloso (1996) showed that fluctuations in population density were frequent in talitrids and indicated periods of intense reproduction. They observed, in fact, similar patterns of variation for Talorchestia quoyana and Pseudorchestoidea brasiliensis, respectively, with highest densities in summer and late winter.

The distribution of amphipod species in the different lagoons was investigated according to environmental factors using PCA analysis. Our statistical analyses indicated that the variation in the spatial distribution of amphipod species depended on some climatic (temperature, humidity) as well as edaphic factors, which was influenced by soil quality. In the different lagoons, T. saltator, found only in the supralittoral zone of Bizerte and El Bibane lagoons, was correlated with temperature, humidity, particle size, and some heavy metals. In sebkhas and oueds, this species was correlated only with edaphic factors (unpublished data). Several studies were focused on the role of environmental factors and showed the influence of factors than others (Borgioli et al. 1999; Scapini et al. 1995; Scapini and Fasinella 1990; Scapini et al. 1999; Scapini and Quochi 1992). Jelassi et al. (2012) showed that Talitridae abundance was tightly controlled by air temperature. The highest abundance observed in this site could be also explained by the important recruitment in spring (Jelassi 2014). Studying the amphipod diversity at three Tunisian lagoon complexes, Jelassi et al. (2013c) showed that according to the constrained correspondence analysis, the abundance of $O$. mediterranea and O. gammarellus at the three lagoon complexes in northern Tunisia could be best explained by the soil contents of several heavy metals, namely zinc, thallium, and cadmium and the proportion of the coarse sand fraction. T. saltator abundance, by contrast, negatively corresponded to these station characteristics. Air and soil temperature were the best predictors for O. stephenseni abundance that negatively corresponded with the proportion of the fine sand fraction and the organic matter content of the soil. O. montagui and C. cavimana abundances corresponded positively with air humidity and the soil lithium and rubidium contents but negatively with the soil tin content and the proportion of the silt and clay fraction. $D$. deshayesii and P. platensis did not exhibit any clear correspondence with station characteristics. Bouslama et al. (2009) showed that the temperature was the most important factor influencing the zonation; indeed, the increase of temperature induced the migration of $\mathrm{T}$. saltator population from the top to the bottom of beach. This result was similar to that found by Fallaci et al. (2003) that reported that the mean zonation of $T$. saltator was exclusively influenced by the temperature during the activity period.
Marques et al. (2003) have highlighted a positive correlation between temperature and the density or biomass of Talitrus saltator population. These authors showed that the positive correlation may be interpreted as a cause-andeffect relation, with temperature favoring recruitment and, consequently, the increase in density and biomass. On the other hand, Colombini et al. (2002) noted the importance of the parameters of the sediment in the choice of specific distribution area especially for young individuals.

\section{Conclusions}

A total of 1,340 talitrids individuals was collected in different coastal lagoons. Abundance, density and diversity were more pronounced in the supralittoral zone of Bizerte lagoon characterized by the presence of eight amphipod species: O. montagui, O. gammarellus, O. mediterranea, O. stephenseni, O. cavimana, P. platensis, D. deshayesii and T. saltator. Moreover, according to principal component analysis, the spatial distribution of species in the different lagoons in Tunisia depends on edaphic (heavy metals, granulometry, organic matter) and climatic (temperature, humidity) factors.

\section{Competing interests}

The authors declare that they have no competing interests.

\section{Authors' contributions}

All the authors performed the field sampling, participated and coordinated in the design and analysis of the study, and drafted the manuscript. All authors read and approved the final manuscript.

\section{Acknowledgements}

The study was supported by the Research Unit of Bio-ecology and Evolutionary Systematics (UR11ES11), Faculty of Science of Tunis, University of Tunis El Manar, University of Salzburg, and the University of Kiel.

\section{Author details}

${ }^{1}$ Université de Tunis El Manar II, Faculté des Sciences de Tunis, Unité de recherche Bio-Écologie et Systématique Évolutive, Tunis, Tunisie. ${ }^{2} \mathrm{FB}$ Organismische Biologie, AG Ökologie, Biodiversität \& Evolution der Tiere, Universität Salzburg, Salzburg, Austria. ${ }^{3}$ Institut für Geowissenschaften, ICP-MS Labor, Universität zu Kiel, Kiel, Germany.

Received: 7 May 2014 Accepted: 25 December 2014

Published online: 16 January 2015

\section{References}

Alfonso MI, Bandera ME, Lopez-Gonzalez PJ, Garcia-Gomez JC (1998) The Cumacean community associated with a seaweed as a bioindicator of environmental conditions in the Algeciras Bay (Strait of Gibraltor). Cah Biol Mar 39:197-205

Ayari A (2012) Eco-éthologie de deux espèces sympatriques Talitrus saltator et Deshayesorchestia deshayesi (Crustacés, Amphipodes) au niveau de deux plages tunisiennes. Thèse de doctorat Faculté des Sciences de Tunis, Université de Tunis El Manar Tunisie, pp 210

Ayari A, Nasri-Ammar K (2012a) Seasonal variation of the endogenous rhythm in tow sympatrics amphipod: Talitrus saltator and Deshayesorchestia deshayesii from Bizerte beach (North of Tunisia). Biol Rhythm Res 43(5):515-526

Ayari A, Nasri-Ammar K (2012b) Locomotor rhythm phenology of Talitrus saltator from two geomorphologically different beaches of Tunisia: Bizerte (North of Tunisia) and Gabes gulf (South of Tunisia). Biol Rhythm Res 43(2):113-123 
Ayari A, Nasri-Ammar K (2011) Distribution and biology of amphipods in two geomorphologically different sandy beaches of Tunisia. Crustaceana 84(5-6):591-599

Bat L, Raffaelli D (1999) Effects of gut sediment contents on heavy metal levels in the amphipod Corophium volutator (Pallas). Turk J Zool 23:67-71

Benrejeb-Jenhani A, Romdhane MS (2002) Impact des perturbations anthropiques sur l'évolution du phytoplancton de la lagune de Boughrara, (Tunisie). Bull Inst Natn Scien Tech Mer de Salammbô 29:65-75

Bergerard J (1989) Ecologie des laisses de marée. Ann Biol 28:39-54

Borgioli C, Martelli L, Porri F, D'Elia A, Marchetti GM, Scapini F (1999) Orientation in Talitrus saltator (Montagu): trends in intrapopulation variability related to environmental and intrinsic factors. J Exp Mar Biol Ecol 238:29-47

Boucheseiche C, Cremille E, Pelte T, Pojer K (2002) Bassin Rhône -MéditerranéeCorse. Guide technique $n^{\circ} 7$, Pollution toxique et écotoxicologie: notion de base. Agence de l'Eau Rhône - Méditerranée - Corse, Lyon

Bouslama MF, El Gtari M, Charfi-Cheikhrouha F (2009) Impact of environmental factors on zonation, abundance, and other biological parameters of two Tunisian populations of Talitrus saltator (Amphipoda, Talitridae). Crustaceana 82(2):141-157

Bulnheim HP, Schwenzer DE (1999) Allozyme variation and genetic divergence in populations of Talitrus saltator (Crustacea: Amphipoda) around the Atlantic coast, the Azores and the Canary Islands. Cah Biol Mar 40:185-194

Cardoso RS, Veloso VG (1996) Population biology and secondary production of the sandhopper Pseudorchestoidea brasiliensis (Amphipoda: Talitridae) at Prainha Beach, Brazil. Mar Ecol Progr Ser 142:111-119

Charfi-Cheikhrouha F, El Gtari M, Bouslama MF (2000) Distribution and reproduction of two sandhoppers, Talitrus saltator and Talorchestia brito from Zouaraa beach-dune system (Tunisia). Pol Arch Hydrobiol 43:621-629

Clarke KR, Warwick RM (1994) Change in marine communities: an approach to statistical analysis and interpretation. Nat Environ Res Council, Plymouth Marine Biological Laboratory, Plymouth, UK

Colombini I, Aloia A, Bouslama MF, El Gtari M, Fallaci M, Ronconi L, Scapini F, Chelazzi L (2002) Small-scale spatial and seasonal differences in the distribution of beach arthropods on the northern Tunisian coasts. Are species evenly distributed along the shore? Mar Biol 140:1001-1012

Corbera J, Cardell MJ (1995) Cumaceans as indicators of eutrophication on soft bottoms. Sci Mar 59:63-69

Dahl E (1946) The Amphipoda of the sound. I: terrestrial Amphipoda. Acta Univ Lundensis 42:1-53

Dauvin JC, Bellan G, Bellan-Santini D, Castric A, Comolet-Tirman J, Francour P, Gentil F, Girard A, Gofas S, Mahé C, Noël P, De Reviers B (1994) Typologie des ZNIEFF Mer. Liste des paramètres et des biocénoses des côtes françaises métropolitaines. Patrimoines Naturels 12:1-64

De Matthaeis E, Cobolli M, Mattoccia M, Scapini F (1995) Geographic variation in Talitrus saltator (Crustacea, Amphipoda): biochemical evidence. Boll Zool 62:77-84

Defeo O, McLachlan A (2005) Patterns, processes and regulatory mechanisms in sandy beach macrofauna: a multi-scale analysis. Mar Ecol Prog Ser 295:1-20

Elkaïm B, Irlinger JP, Pichard S (1985) Dynamique de la population d'Orchestia mediterranea L. (Crustacé, Amphipode) dans l'estuaire du Bou Regreg (Maroc). Can J Zool 63:2800-2809

Fallaci M, Aloia A, Audoglio M, Colombini I, Scapini F, Chelazzi L (1999) Differences in behavioural strategies between two sympatric talitrids (Amphipoda) inhabiting an exposed sandy beach of the French Atlantic coast. Estuar Coast Shelf Sci 48:469-482

Fallaci M, Colombini I, Lagar M, Scapini F, Chelazzi L (2003) Distribution patterns of different age classes and sexes in a Tyrrhenian population of Talitrus saltator (Montagu). Mar Biol 142:101-110

Fialkowski W, Rainbow PS, Fialkowska E, Smith BD (2000) Biomonitoring of trace metals along the Baltic Coast of Poland using the sandhopper Talitrus saltator (Montagu) (Crustacea: Amphipoda). Ophelia 52:183-192

Förstner U, Wittmann GTW (1981) Metal pollution in the aquatic environment, 2nd edn. Springer, Berlin

Frontier S (1983) Stratégies d'échantillonnage en écologie. Masson, Paris, p 494

Griffiths CL, Stenton-Dozey JME, Koop K (1983) Kelp wrack and the flow of energy through a sandy beach ecosystem. In: McLachlan A, Erasmus T (eds) Sandy Beaches as Ecosystems. Junk Publications, The Hague, pp 547-556

Henin S (1983) Les éléments traces dans les sols. Science Du Sol 2:67-71

Ikem A, Egiebor NO (2005) Assessment of trace elements in canned fishes (mackerel, tuna, salmon, sardines and herrings) marketed in Georgia and Alabama (United States of America). J Food Comp Anal 18:771-787
Islam MS, Tanaka M (2004) Impacts of pollution on coastal and marine ecosystems including coastal and marine fisheries and approach for management: a review and synthesis. Mar Poll Bull 48:624-649

Jelassi R (2014) Eco-éthologie des peuplements d'Amphipodes au niveau des zones humides de la Tunisie. Thèse de doctorat Université de Tunis, Tunisie, p 328

Jelassi R, Nasri-Ammar K (2013) Seasonal variation of locomotor activity rhythm of Orchestia montagui in the supralittoral zone of Bizerte lagoon (North of Tunisia). Biol Rhythm Res 44(5):718-729

Jelassi R, Khemaissia H, Nasri-Ammar K (2012) Intra-annual variation of the spatiotemporal distribution and abundance of Talitridae and Oniscidea (Crustacea, Peracarida) at Bizerte Lagoon (northern Tunisia). Afr J Ecol 50:381-392

Jelassi R, Ayari A, Nasri-Ammar K (2013a) Seasonal variation of locomotor activity rhythm of Orchestia gammarellus in the supralittoral zone of Ghar Melh lagoon (North-East of Tunisia). Biol Rhythm Res 44(6):956-967

Jelassi R, Akkari-Ayari A, Bohli-Abderrazak D, Nasri-Ammar K (2013b) Endogenous locomotor activity rhythm of two sympatric species of Talitrids (Crustacea, Amphipoda) from the supralittoral zone of Bizerte lagoon (Northern Tunisia). Biol Rhythm Res 44(2):265-275

Jelassi R, Zimmer M, Khemaissia H, Garbe-Schönberg D, Nasri-Ammar K (2013c) Amphipod diversity at three Tunisian lagoon complexes in relation to environmental conditions. J Nat His 47(45-46):2849-2868

Koch $\mathrm{H}$ (1989) The effect of tidal inundation on the activity and behavior of the supralittoral talitrid amphipod Traskorchestia traskiana. Crustaceana 57:295-303

Louis M (1980) Etude d'un peuplement mixte d'Orchestia montagui Audouin et d'Orchestia deshayesii Audouin dans la baie de Bou Ismail. Bull Ecol 11:97-111

Marques JC, Gonçalves SC, Pardal MA, Chelazzi L, Colombini I, Fallaci M, Bouslama MF, El Gtari M, Charfi-Cheikhrouha F, Scapini F (2003) Comparison of T. Saltator (Amphipoda, Talitridae) biology, dynamics and secondary production in Atlantic (Portugal) and Mediterranean (Italy and Tunisia) populations. Estuar Coast Shelf Sci 58:127-148

Marsden ID (1991) Kelp-sandhopper interactions on a sand beach in New Island. II. Population dynamics of Talorchestia quoyana (Milne-Edwards). J Exp Mar Biol Ecol 152:75-90

McLachlan A, Brown AC (2006) The ecology of sandy shores second ed. Elsevier, Amsterdam, p 392

McLachlan A, Jaramillo E (1995) Zonation on sandy beaches. Oceanogr Mar Biol Ann Review 33:305-335

Medail F, Quezel P (1999) Biodiversity hotspots in the Mediterranean basin: setting global conservation priorities. Conserv Biol 13:1510-1513

Nasri-Ammar K, Morgan E (2005) Variation saisonnière du rythme de l'activité locomotrice de Talitrus saltator issu de la plage de Korba (Cap Bon, Tunisie). Bull Soc Zool Fr 130(1):19-29

Nasri-Ammar K, Morgan E (2006) Seasonality of the endogenous activity rhythm in Talitrus saltator (Montagu) from a sandy beach in north-eastern Tunisia. Biol Rhythm Res 37:479-488

Pérez-Domingo S, Castellanos C, Junoy J (2008) The sandy beach macrofauna of Gulf of Gabès (Tunisia). Mar Ecol 29:51-59

Phillips DJH, Rainbow PS (1994) Biomonitoring of trace aquatic contaminants, Environmental Management Series. Chapman and Hall, London

Pielou EC (1966) The measurement of diversity in different types of biological collections. J Theor Biol 13:131-144

Rainbow PS, Moore PG, Watson D (1989) Talitrid amphipods (Crustacea) as biomonitors for copper and zinc. Estuar Coast Shelf Sci 28:567-582

Ruffo S (1993) The Amphipoda of Mediterranean. Part IV: Localities and map-Agenda to parts 1-3-Key to families-Ecology-Faunistics and zoogeography. Mem Inst Oceanogr de Monaco 13:959

Ruffo S, Tarocco M, Latella L (2014) Cryptorchestia garbinii n. sp. (Amphipoda: Talitridae) from Lake Garda (Northern Italy), previously referred to as Orchestia cavimana Heller, 1865, and notes on the distribution of the two species. Ital J Zool 81:91-98

Scapini F, Fasinella D (1990) Genetic determination and plasticity in the sun orientation of natural populations of Talitrus saltator. Mar Biol 107:141-145

Scapini F, Quochi G (1992) Orientation in sandhoppers from Italian populations: have they magnetic orientation ability? Bull Zool 59:437-442

Scapini F, Lagar MC, Mezzetti MC (1993) The use of slope and visual information in sandhoppers: innateness and plasticity. Mar Biol 115:545-553 
Scapini F, Buiatti M, De Matthaeis E, Mattoccia M (1995) Orientation behaviour and heterozygosity of sandhopper populations in relation to stability of beach environments. J Evol Biol 8:43-52

Scapini F, Porri F, Borgioli C, Martelli L (1999) Solar orientation of adult and laboratory-born juvenile sandhoppers: inter- and intra-population variation. J Exp Mar Biol Ecol 238:107-126

Schlacher TA, Dugan J, Schoeman DS, Lastra M, Jones A, Scapini F, Mclachlan A, Defeo O (2007) Sandy beaches at the brink. Divers Distrib 13:556-560

Simpson EH (1949) Measurement of diversity. Nature 163:672-688

Weeks JM (1992) The use of the terrestrial amphipod Arcitalitrus dorrieni (Crustacea: Amphipoda: Talitridae) as a potential biomonitor of ambient zinc and copper availabilities in leaf-litter. Chemosphere 24:1505-1522

Wildish DJ (1988) Ecology and natural history of aquatic Talitroidea. Can J Zool 66:2340-2359

Williams JA (1995) Burrow-zone distribution of the supralittoral Amphipod Talitrus saltator on Derbyhaven beach, Isle of Man - a possible mechanism for regulating desiccation stress? J Crust Biol 15:466-475

\section{Submit your manuscript to a SpringerOpen ${ }^{\circ}$} journal and benefit from:

- Convenient online submission

- Rigorous peer review

- Immediate publication on acceptance

- Open access: articles freely available online

- High visibility within the field

- Retaining the copyright to your article 